\title{
Learning Physics through Project-Based Learning Game Techniques
}

\author{
Medine Baran \\ Dr., Dicle University, Education Faculty, Turkey, medabaran@gmail.com
}

Abdulkadir Maskan

Prof., Dicle University, Education Faculty, Turkey, akmaskan@gmail.com

\section{Şeyma Yaşar}

Provincial Directorate of National Education, Turkey, symyasar@hotmail.com

The aim of the present study, in which Project and game techniques are used together, is to examine the impact of project-based learning games on students' physics achievement. Participants of the study consist of 34 9th grade students $(\mathrm{N}=34)$. The data were collected using achievement tests and a questionnaire. Throughout the applications, the physics teacher taught the course to the experimental group using activities involving games with the project-based learning method while processing the control group students according to traditional method. Data obtained at the end of the study were analyzed using independent, dependent groups t-test and Mann-Whitney U test, content analysis and descriptive analysis methods. At the end of the study, it was found that the mean of the concept achievement post-test scores of the students in the experimental group differ significantly. Moreover, students in the experimental group indicated that they had enjoyed the implementation of the activities. And they thought that this method should be applied in all physics classes because it had positively affected their attitudes toward the subject and were motivating. The self-assessment forms completed by the participants in the experimental group also revealed a range of opinions regarding the applications, both positive and negative.

Keywords: project based learning, gaming technique, physics success, self-evaluation, teaching, learning

\section{INTRODUCTION}

Most students perceive physics as a difficult subject and experience significant problems in transforming physics-related concepts into concrete understanding of the subject. Meanwhile, the question remains: why is it that, although they encounter physics related concepts in action so frequently in their daily lives, students have such difficulties in comprehensively learning and concretizing physics? Many studies have been conducted

Citation: Baran, M., Maskan, A., \& Yaşar, Ş. (2018). Learning Physics through Project-Based Learning Game Techniques. International Journal of Instruction, 11(2), 221-234. https://doi.org/10.12973/iji.2018.11215a 
in order to answer this question. In most of the studies conducted, it was concluded that students were more successful when they were actively involved in the class and able to link the concepts with the daily life. In parallel with this, it can be said that the methods and techniques applied in learning environments are key to the level of learners' access to information. It is possible to assert that teaching methods and techniques that provide learners with the means to accurately structure and monitor their own learning are much more effective than traditional method, which uses the dialogue techniques.

Studies have illustrated that project-based learning in which students are particularly active contribute to meaningful learning (Baran, 2007; Kızkapan\& Bektaş, 2017). Within the framework of the constructivist learning approach, project-based learning is one of the effective student centered learning methods that allows the students to learn by doing. Learning with games is another student-centered method that can draw the learner into the center of learning through dynamic learning activities. Games that are inherently present in learners' nature are prominent in meaningful learning. Particularly, the use of games in learning activities that involve the basics of everyday life positively impacts their affective development while making meaningful learning enjoyable.

One of the advantages of student-centered methods is that students can give self-peer evaluation opportunities. So that the student can share his / her thoughts about himself / herself and others. The student is also active in evaluation, giving the student the feeling of feeling valuable. Moreover, "Peer assessment can drive students to evaluate their working performance compared to their friends' working performance. Evaluation refers to the highly excellent way of thinking which also requires students to evaluate other students' performance so they could do a reflection and make it their learning experience (de Raadt et al., 2005; cited in Pantiwati \& Husamah, 2017). At its core, Project Based Learning is an approach designed to develop desirable learner characteristics such as research skills, self-confidence, responsibility and cooperation, through activities in which learners work individually or in groups to design a plan and a program in a limited time period for the purpose of creating a product (Ülküdür \& Bacanak, 2013). In the lessons where project-based learning is employed, students can easily link the content knowledge to everyday life. Strategies involving real-life applications and linkages increase students' desire for learning (Lock et al, 2015). With project-based learning, the learning process in learning environments is linked to dailylife where students are required to establish their own learner profiles and learn how to learn while they solve real-life problems through using previously acquired knowledge (Ay, 2013).

With the application of the project-based learning approach in learning environments, the development of students' skills and beliefs such as group work skills, life skills, (managing meetings, planning, budgeting, etc.), cognitive processing skills (decision making, critical thinking, problem solving, etc.) self-management skills (setting goals, organizing tasks, time management, etc.) attitudes (love of learning, willingness to further education), personal trends (self-direction, sense of accomplishment), beliefs (self-sufficiency) are significantly affected (Yurtluk, 2003). 
Additionally, it is possible to say reflective learning skills, which is important to meaningful learning with project-based learning have also improved. With project-based learning, students have the opportunity to significantly improve their scientific processing skills through questions, discussions, observations and predictions, conducting experiments, collecting and analyzing data, and ultimately reaching conclusions and sharing findings (Blumenfeld et al, 1991, Westwood, 2006, cited in Kizkapan \& Bektas, 2017). Project-based learning activities that are heavily practiced in science fields are well suited for physics courses. The principles and theories of physics in all areas of daily life are very suitable for project-based learning applications where everyday life problems are central. In this manner, students can find ways to solve physics problems selected (adapted) from everyday life and to acquire the opportunity of learning by doing and concretizing physics lessons. Using project-based learning, students actively participate in solving the given physics problems. It can be argued that, in addition to improving the learners' attitudes and motivation to physics classes, teaching with project-based learning activities can lead to greater student achievement. In other words, the project-based learning is an effective approach for the development of students' cognitive, emotional and psychomotor skills.

While they appeal to all people, children in particular are attracted to games. For this reason, students are generally more eager to participate in educational activities that involve games. For all children who have been immersed in playing games at an early age, learning through games can be more fun. According to Gözalan and Koçak (2014), 'game' is defined as a fun activity in whose goal is to develop social harmony and emotional maturity through the use of physical and mental skills, which takes place in an environment other than real life, does not result in financial gain, has its own specific rules, is limited to a particular space and time, where social groups formed through voluntary participation and involves all participants. It is stated that educational activities in which the games are used increase students' success and facilitate learning (Bottino et al, 2007). If this fun, happening activity can be implemented in the learning environment by taking into consideration the student characteristics, successful results can be obtained in areas such as physics classes where students are often afraid and close to prejudice. Scientific principles and theories, especially those that are constantly encountered by students in everyday life through games can contribute to academic success, as well as emotional development. Games and toys, which are useful and effective in motivating learners during classroom demonstration activities, have been used intensively for a long time in physics classes (Guemez et al, 1987; cited in Korhonen, 2010).

As the literature indicated that in experimental studies project-based learning methods and game techniques have not been applied together in physics education. None of the studies used project-based learning method along with game technique. This constitutes an important deficiency in the literature. In order to fill this gap in the literature, based on premise that learners should play an active role in accessing information, this study in which project and game techniques are used simultaneously, aims to examine the effects of project based learning games on students' achievement in $9^{\text {th }}$ grade physics classes. In this research, the goal is to enhance participating students' cognitive, affective and 
psychomotor development. Along similar lines, the research method used in the current study can inform potential student-centered studies in other academic fields and grade levels.

\section{METHOD \\ Participants}

This study was conducted with $34(\mathrm{~N}=34)$ participants enrolled in the $9^{\text {th }}$ grade of a Technical and Industrial Vocational High School in Diyarbakır/Turkey. In this quasiexperimental study, $21(\mathrm{n}=21)$ students were assigned to the experimental group, while $13(n=13)$ were in the control group. The participants were selected using purposeful sampling methods. The sample was selected from the 9 th grade students who are closer to the game age.

\section{Data Collection Tools}

In the study, data collection tools included, a 17-item Newton's Law of Motion Concept Achievement Test (pre assessed for validity and reliability by the researchers). Moreover a 5-item, open-ended questionnaire developed by the researchers was used as post test. In addition, 16-item self-evaluation form (developed by Akçinar et al, 2017) indicating the experimental group participants' opinions and evaluations regarding the process were collected to obtain supporting / supplementary data. The Newton's Law of Motion Concept Achievement Test was designed based on the works of Şalgam (2009) and Atasoy and Akdeniz (2007).

Before the beginning of the main applications $8110^{\text {th }}$ grade students were given the Newton's Law of Motion Concept Achievement Test to approve reliability. The reliability coefficient was calculated as 0.69 in the pilot study. The open-ended questionnaire and the test questions were reviewed by experts in physics, educational assessment and evaluation, as well as linguists to ensure the validity and reliability.

\section{Procedure}

The application of the procedures lasted for a total of 5 weeks. This 5 -week period does not include pre-test and post-test periods. At the beginning of the study, Newton's Law of Motion Law Concept Achievement Test was administered to both experimental and control group participants as a pre-test. Early on, the participants in the experimental group were provided with information regarding the applications. The study topics were determined by the researchers and the participants were divided into 7 groups and asked to design game tool projects appropriate for the assigned topics.

Project topics

1- Friction Coefficient (Kinetic and Static Friction Coefficient)

2- Law of Inertia

3- Basic Law of Dynamics

4- Law of Action-Reaction

Project topics as determined by students and course teacher

1. Rocket car (Law of Action-Reaction)

2. Swing (Newton's Second Law of Motion)

3. Dominos (Law of Action-Reaction; Newton's Second Law of Motion) 
4. Slide (Law of Friction; Newton's Second Law of Motion)

5. Bumper carts (Law of Action-Reaction; Law of Inertia)

6. Carousel (Law of Inertia)

7. Billiard (Law of Action-Reaction; Newton's Second Law of Motion)

8. Bowling balls with Newton's cradle (Law of Action-Reaction)

9. Glass and metal coin game (Law of Inertia)

10. Golf (Law of Inertia, Law of Friction)

11. Ball spinning (Law of Inertia, Law of Friction)

12.Arrow (Law of Action-Reaction)

Students who were facing difficulties in the phase of deciding on a project topic were offered help by the teacher. Participants in the experimental group have designed their game tools based on Newton's Laws of Motion in the classroom setting in 4 weeks. In the fifth week, students in the experimental group presented the game systems they designed based on Newton's Laws of Motion to their classmates. During the same time period, students in the control group received instruction on the same topics using current teaching methods and techniques.

Sample recordings of activities undertaken by the experimental group participants are presented below.

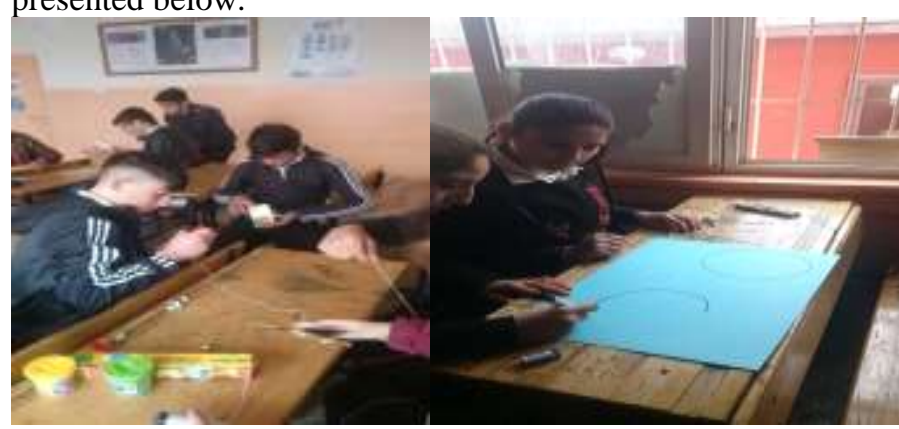

Figure 1

Image of experimental group students while making their game tools

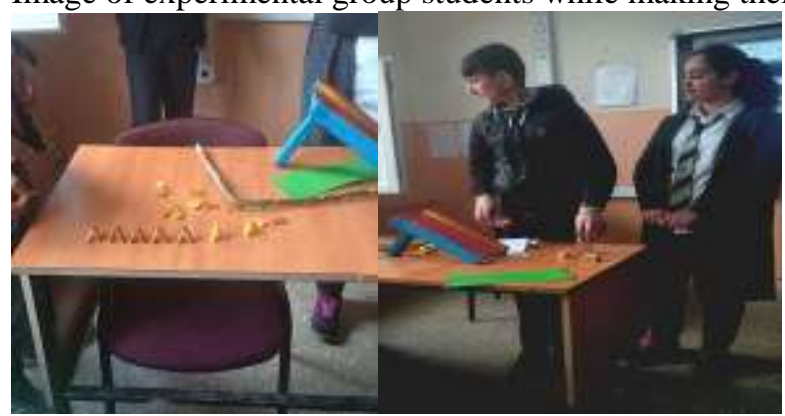

Figure 2

Students presented the slide and Dominos (Law of Action-Reaction; Newton's Second Law of Motion) they designed based on Newton's Laws of Motion to the participants in the experimental group. 


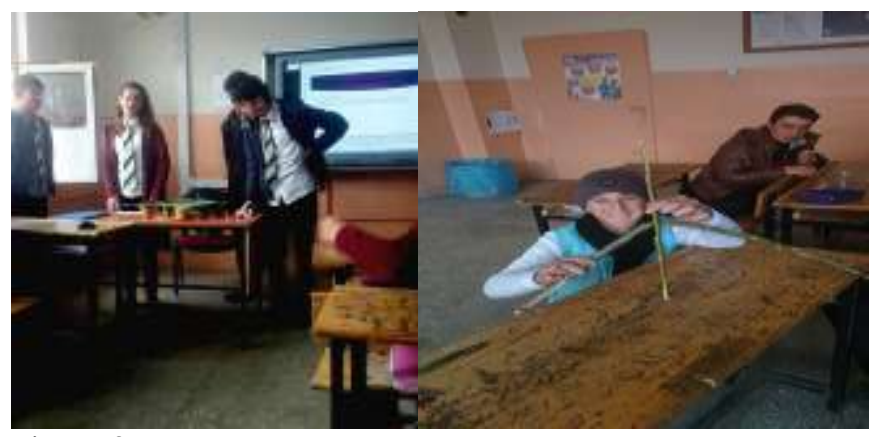

Figure 3

The students explain Newton's Laws of Motion to the participants of the experimental group based on the billiard table they designed (Law of Action-Reaction; Newton's Second Law of Motion).

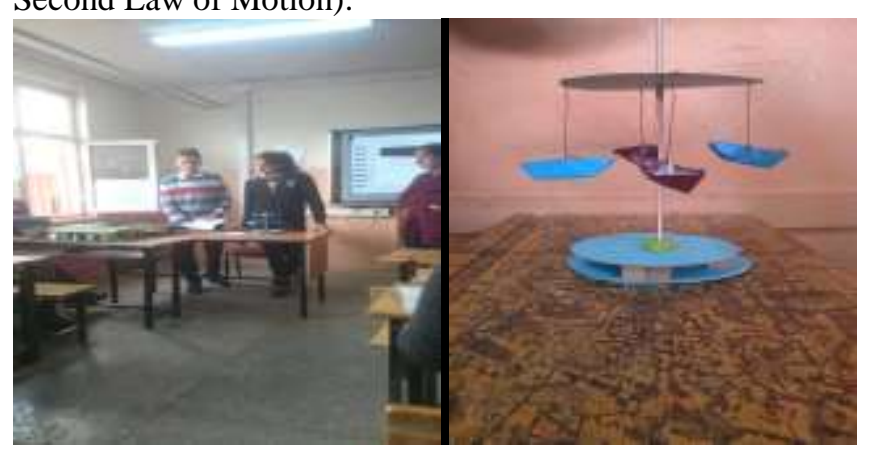

Figure 4

The students explain Newton's Laws of Motion to the participants of the experimental group based on the carousel (Law of Inertia) and the glass game (Law of Inertia) they designed.

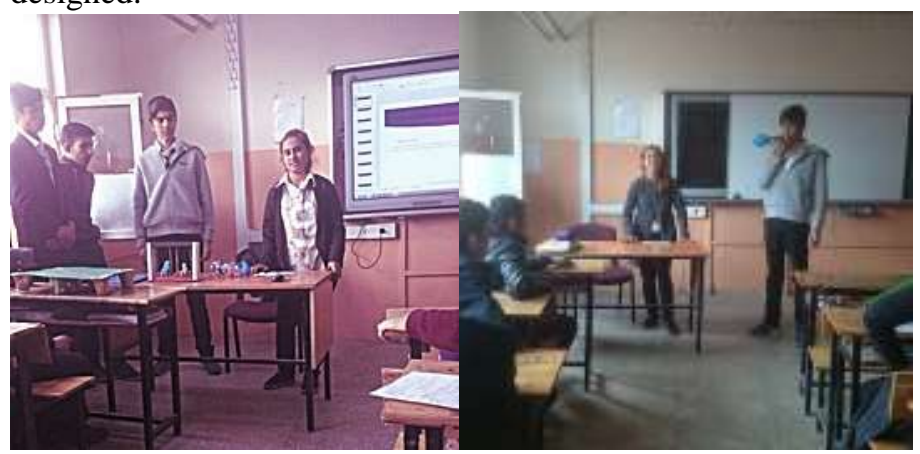

Figure 5

The students explain Newton's Laws of Motion to the participants of the experimental group based on the Rocket car (Law of Action-Reaction) Swing (Newton's Second Law of Motion) they designed. 


\section{Data Analysis}

The quantitative data obtained at the end of the study were analyzed using the independent $t$ test, Wilxocon signed rank test and the Mann-Whitney $U$ test. The qualitative data was analyzed using content analysis and descriptive analysis methods.

\section{FINDINGS}

After the data were analyzed the average scores attained by the participants in the experimental group and the control group on Newton's Laws Concept Achievement pre post test were compared (in table 1,2,3 and 4) and the experimental group participants' self and peer-evaluation results were obtained (in table 5 and 6).

Table 1

Analysis results of pre-test achievement test

\begin{tabular}{lllllll}
\hline & Group & $\mathrm{N}$ & Mean & Std. Deviation & $\mathrm{t}$ & $\mathrm{p}$ \\
\hline \multirow{2}{*}{ Pre-test } & Experimental & 21 & 3.4500 & 1.60509 & -.156 & .877 \\
\cline { 2 - 7 } & Control & 13 & 3.5385 & 1.56074 & & \\
\hline
\end{tabular}

Levene's test $\mathrm{p}$ value: .837 ( $\mathrm{p}>.05)$

No significant difference was found among the average scores obtained by the participant on Newton's Laws Concept Achievement Test ( $p>.05)$. Based on this result, it may be concluded that students in both groups are equal in terms of achievement.

Table 2

Wilxocon signed rank test analysis results of control groups' students

\begin{tabular}{|c|c|c|c|c|c|c|}
\hline Scores & & $\mathrm{N}$ & Mean Rank & Sum of Ranks & $\mathrm{Z}$ & $\mathrm{p}$ \\
\hline \multirow{4}{*}{$\begin{array}{l}\text { Posttest Scores } \\
\text { Pretest Scores }\end{array}$} & Negative Ranks & 3 & 4.50 & 13.50 & \multirow[t]{4}{*}{-2.069} & \multirow{4}{*}{.039} \\
\hline & Positive Ranks & 9 & 7.17 & 64.50 & & \\
\hline & Ties & 1 & & & & \\
\hline & Total & 13 & & & & \\
\hline
\end{tabular}

It was determined that students who participated in the study had significantly higher end-test point averages $(\mathrm{p}<.05)$ at the end of the process

Table 3

Wilxocon signed rank test analysis results of experimental groups' students

\begin{tabular}{llrrrrr}
\hline Scores & & $\mathrm{N}$ & Mean Rank & Sum of Ranks & $\mathrm{Z}$ & $\mathrm{p}$ \\
\hline \multirow{3}{*}{$\begin{array}{l}\text { Posttest Scores } \\
\text { Pretest Scores }\end{array}$} & Negative Ranks & 1 & 1.00 & 1.00 & -3.790 & .000 \\
\cline { 2 - 6 } & Positive Ranks & 18 & 10.50 & 189.00 & & \\
\cline { 2 - 6 } & Ties & 1 & & & \\
\cline { 2 - 6 } & Total & 20 & & & \\
\hline
\end{tabular}

It was determined that students who participated in the study had significantly higher end-test point averages $(\mathrm{p}<.05)$ at the end of the process

Table 4

Mann Whitney $U$ test analysis results of posttest point averages of the students of experimental and control group

\begin{tabular}{llllllc}
\hline Group & & $\mathrm{N}$ & Mean & Std. Deviation & $\mathrm{Z}$ & $\mathrm{p}$ \\
\hline Post- & Experimental & 21 & 9.4500 & 2.50210 & -4.120 & .000 \\
\cline { 2 - 7 } Sum & Control & 13 & 4.9231 & 1.11516 & & \\
\hline
\end{tabular}

Levene's test $\mathrm{p}$ value:.019 $(\mathrm{p}<.05)$ 
At the end of the study, the students in the experimental group were found to be more successful than the students in the control group $(p<.05)$ when the final test success point average of the experimental and control groups was compared. It is possible to say that the new method applied here is more effective than the current teaching method.

Table 5

Distributions of the participating students' average scores on the open-ended questionnaire

\begin{tabular}{lllllll}
\hline & Group & $\mathrm{N}$ & Mean & Std. Deviation & $\mathrm{t}$ & $\mathrm{p}$ \\
\hline \multirow{2}{*}{ Total } & Experimental & 21 & 8.38 & 2.202 & 7.565 & .000 \\
\cline { 2 - 6 } & Control & 13 & 3.21 & 1.578 & & \\
\hline
\end{tabular}

Levene's p value: 269 (p>.05)

Responses to the open-ended questionnaire were scored using the triad rating system. The scoring was based on s/he knows: $0=$ none at all, $1=$ partially; $3=$ completely. Participants' scores on the open-ended questionnaires and the written exam administered by the teacher revealed that the students in the experimental group have achieved a greater level of success when compared to those in the control group. Based on these findings, it may be concluded that the method applied had a positive effect on the students' performance level in the physics class.

Table 6

Distributions of the experimental group participants' scores on the self-evaluation forms

\begin{tabular}{llllll}
\hline & $\mathrm{N}$ & Minimum & Maximum & Mean & Std. Deviation \\
\hline Total & 21 & 19.00 & 36.00 & 30.4286 & 4.73890 \\
\hline Average & 21 & 1.58 & 3.00 & 2.5357 & .39491 \\
\hline
\end{tabular}

$3=$ Above average, 2 = average, $1=$ Below average

Table 6 shows that, in their responses to the group self-evaluation statements, the participants in the experimental group have scored within the range of average and above average $(X=2.53)$. Based on these findings, it can be concluded that, in general, the participants in the experimental group evaluation were positive.

Table 7

Analysis results of students' self-evaluation form in the experimental group

\begin{tabular}{|c|c|c|}
\hline Theme & Codes & $\mathrm{F}$ \\
\hline \multirow{5}{*}{$\begin{array}{l}\text { The most significant challenge } \\
\text { faced during the activity: }\end{array}$} & Presentation & 12 \\
\hline & Lack of time & 1 \\
\hline & Golf ball not getting into the hole & 2 \\
\hline & There were no problems & 6 \\
\hline & Difficulty in finding the materials & 3 \\
\hline \multirow[t]{7}{*}{ The source of the problem: } & Excitement & 9 \\
\hline & There were no problems & 7 \\
\hline & Implementation phase & \\
\hline & the cardboard was uneven & 2 \\
\hline & the distance between participants place of residence & 2 \\
\hline & Irresponsibility of the friends & 2 \\
\hline & The car's moving backwards & 1 \\
\hline The best aspect : & We did well in all aspects & 2 \\
\hline
\end{tabular}




\begin{tabular}{lll}
\hline & Presentation & 3 \\
\cline { 2 - 2 } & Group work & 8 \\
\cline { 2 - 2 } & Responsibility & 1 \\
\cline { 2 - 3 } & Implementation and preparation phases & 1 \\
\hline \multirow{3}{*}{$\begin{array}{l}\text { The group could have } \\
\text { performed better if, }\end{array}$} & The project topic were not so short & 5 \\
\cline { 2 - 3 } & We were given more responsibility & 2 \\
\cline { 2 - 3 } & There were no lack of trust & 2 \\
\cline { 2 - 3 } & We had less anxiety during the presentation & There were no lack of materials \\
\cline { 2 - 3 }
\end{tabular}

As can be seen in Table 7, the students in the experimental group reported that the most challenging phase was the presentation, due to anxiety. Based on the findings obtained from the self-evaluation forms completed by the participants in the experimental group, the students have mostly enjoyed the teamwork, implementation and preparation phases. They have also reported that their teammates should have taken on more responsibility.

In addition to the findings obtained from the self-evaluation forms, in the interviews conducted with the participants of the experimental group, students reported that they enjoyed and benefitted from learning Newton's Laws in this manner, and added that they would like to see this method in different lessons. For instance, student A stated, "Because it has contributed to our lives, and helped us better understand the subject." Similarly, in his statement, student $C$ said, "The lesson goes faster, I understand the subject better, I enjoyed physics class". Another participant, Student B stated, "The application phase of the study was very enjoyable; I liked playing and winning the golf game." Student D shared his/her experience and expressed that s/he thought learning through games was entertaining, "I enjoyed playing with the top and billiards." As far as its implementation in other courses was concerned, interviewees expressed great enthusiasm. For instance, showing their support for using the method in other classes, while Student E said, "using this method will help us like learning more." Student F stated, " Physics and chemistry. in this way, I can be more focused during class."

\section{DISCUSSION}

At the end of the process, it was established that there was a significant increase in the average test scores obtained by the participants of the experimental and control groups $(\mathrm{p}<.05)$. Based on this result, eit can be concluded that participants in both the experimental group and control group have had significant gains in learning Newton's Laws.

At the end of the study, the average post-test scores of the experimental and the control groups were compared, results indicated that the students in the experimental group were more successful than those in the control group who were taught using current teaching method which students may not have a chance to experience in active learning. Similar to this finding, the results obtained from open-ended questionnaire revealed that the participants in the experimental group had achieved significantly higher scores. The fact that the students in the experimental group were more successful than the students in the control group reveals that the implementation of game techniques based on 
project-based learning methods which supported the hypothesis. In this manner, students were not only at the center of learning by doing, they also had the opportunity to have fun while learning through games that are a part of their lives. In fact, in the interviews, the participating students have particularly emphasized the game aspect of the method implemented and stated that they had fun and voiced a desire for the approach to be used in all science courses. In this study, using the most entertaining games appropriate for learning physics the students were able to connect the concepts in physics to daily life through the implementation of the game techniques and project based learning activities.

The literature review of science and physics education studies has revealed that the application of project-based learning methods is rather frequent (Filippatou \& Kaldi, 2010; cited in Kizkapan \& Bektas, 2017). In their study, Hidayah et al, 2015) have combined project-based learning activities with the cognitive approach. The results of their study on fluids, heat and optics indicated an improvement in the creativity level of the experimental group. Similarly, Baran and Maskan (2011)'s quasi-experimental study on high school students revealed that student-centered practices supported by projectbased learning activities have improved learners both emotionally and cognitively. Earlier scientific studies showed that having students undertake project based classwork involving potential problems they may encounter in real life, learning through real life experience, will contribute to the process of making sense of the information they acquire (Çiftçi 2006; Cited in Yilmaz, 2015). In his experimental study, Yilmaz (2015) explored the concept of electricity using a project-based learning method. He found that the project-based learning activities he used in his study positively impacted learner achievement. Project-based learning can increase meaningful learning by applying other methods and techniques. Husamah (2015) stated that blended project based learning has positive effects on students' thinking skills.

The literature review on gaming technique has revealed that, although it is not as old as the project-based learning method, games are used frequently in teaching science and physics (Bourgonjon et al, 2010; cited in Stege et al, 2011; Ketelhut et al, 2006). In his study, using the traditional Gulli-Danda game, Joshi (2014) has stated that traditional games are very effective in teaching momentum, inertia, flexible and inflexible collision concepts. According to the author, games that are traditional in nature can be used as low-cost yet effective tools for teaching physics. In a similar study, Karakaş and Büyükaydin (2016) have examined the teaching of such concepts as angular momentum, balance and force. Based on these concepts, students were instructed to design various types of toys. The authors indicated that the students have benefited from the activities they used. In his study using games, Godzaridus (2004) noted that presenting physics lessons to the students through games helps them realize that physics is not a merely theoretical discipline that can only be studied in well-equipped laboratories. Because just like in the games they play, physics is present in every part of life. It is possible to say that the activities in the physics courses in which both techniques are applied together can contribute to the success of the learner in a greater amount, with a large number of studies showing that there are positive effects of project-based learning and learning of games. In similar studies, Karakaş and Buyukaydin (2016) and Boucher- 
Genesse e $t$ al (2011), have taken on subjects like Newton's laws angular momentum and equilibrium with their own games in physics classes. They found that the method they used had positive effects on the learners' success in physics classes.

In the current study, the participants in the experimental group stated that they were most distressed and nervous during the presentation phase. The students in the experimental group expressed that they enjoyed most of the group work and practice and preparation stages on the basis of the data on the self-evaluation forms and that the friends in the group should take more responsibility. In light of these findings, the problems the participants faced during the presentations phase may be attributed to their lack of public speaking experience and their nervousness during the process. Kara (2008) found that the students in the experimental group generally found group performance to be high, but they were particularly distressed in terms of task sharing and responsibility among the students. It is possible that the participation of students in the evaluation at the end of the process helped them emotionally. Additionally, there are studies indicating that the participation of the students in the evaluation process positively affected their performances (Karakuş, 2006). In literature, project based learning and playing learning techniques have been studied separately. But in this work we used the perfect synthesis of both project-based learning and gaming techniques. We have come to the conclusion that this synthesis affects both the cognitive, emotional and psychomotor dimensions positively. Students were entertained with games and projectbased learning activities, and there was an unimaginable increase in meaningful learning.

\section{CONCLUSION}

In this study, an application which is not very common in the literature (project-based learning- game technique) and the 9th grade physics lesson are discussed. Compared to the current method, it was seen that the applications more positively affected physics success. When the process is considered as a whole, it is possible to say that this method has a positive effect on the students' success in physics, but it also affects participant students positively. Participating students learned Newton's Laws by taking responsibility but at the same time having fun with games. Based on the findings of this study, it is possible to make a positive contribution to the achievement of the students by teaching the science courses that the students like physics lessons with the prejudice and unconstructed lessons with the approach used in this study (project based learning method). In addition, project-based learning methodology is also thought to be beneficial in terms of emotional and psychomotor skills development. Students have also expressed that they had difficulties in finding the necessary materials during the application process. For this reason, in order to achieve positive results, the implementation of project based learning method should be initiated after providing the needed equipment and the appropriate infrastructure. Therefore, in order to use project based learning method and game techniques effectively in science/physics classes, the necessary technical equipment should be in place. Science / physics education is very suitable as subject and scope for these researches. However, it will be beneficial to undertake similar studies in teaching other subjects. 


\section{REFERENCES}

Atasoy, Ş., \& Akdeniz, A.R. (2007). Newton'un hareket kanunlari konusunda kavram yanilgilarini belirlemeye yönelik bir testin geliştirilmesi ve uygulanmasi. Türk Fen Eğitimi Dergisi, 4(1), 45-59.

Ay, S.. (2013). Trainee teachers' views on project-based learning and traditional education. H. U. Journal of Education, 28(1), 53-67.

Baran, M. (2007). Proje tabanlı öğrenme modelinin fizik öğretmenliği ikinci sınıf öğrencilerinin elektrostatik konusu başarısına ve fiziğe yönelik tutumlarına etkisi üzerine bir araştırma. Yüksek Lisans Tezi. Diyarbakır: Dicle Üniversitesi Fen Bilimleri Enstitüsü.

Blumenfeld, P. C., Soloway, E., Marx, R. W., Krajcik, J. S., Guzdial, M., \& Palincsar, A. (1991). Motivating project-based learning: Sustaining the doing, supporting the learning. Educational psychologist, 26(3-4), 369-398.

Bourgonjon, J., Valcke, M., Soetaert, R., \& Schellens, T. (2010). Students' perceptions about the use of video games in the classroom. Computers \& Education, 54, 1145-1156.

Boucher-Genesse,F., Riopel, M., \& Potvin, P. (2011). Research results for Mecanika, a game to learn Newtonian concepts, Games + Learning + Society 2011 conference proceedings. Université du Québec à Montréal,

Bottino, R.M., Ferlino, L., Ott M., \& Tavella, M. (2007). Developing strategic and reasoning abilities with computer games at primary school level, Computers \& Education, 49(4) (2007), 1272-1286.

Çiftçi, S. (2006). Sosyal Bilgiler Öğretiminde Proje Tabanlı Öğrenmenin Öğrencilerin Akademik Risk Alma Düzeylerine, Problem Çözme Becerilerine, Erişilerine, Kalıcıllğa ve Tutumlarına Etkisi, Yayımlanmamış Doktora Tezi, Konya: Selçuk Üniversitesi Sosyal Bilimler Enstitüsü

Filippatou, D., \& Kaldi, S. (2010). The effectiveness of project-based learning on pupils with learning difficulties regarding academic performance, group work and motivation. International Journal of Special Education, 25(1), 17-26.

Gözalan, E., \& Koçak, N. (2014). Oyun temelli dikkat eğitim programının 5-6 yaş çocukların kelime bilgi düzeylerine etkisinin incelenmesi. KMÜ Sosyal ve Ekonomik Araştırmalar Dergisi, 16 (2), 115-121.

Godzaridis, C (2004). Physical education and games, and concepts of Physics: An interdisciplinary approach. Science Education international, 15 (2), 161-166.

Guemez J, Fiolhais C.,\& Fiolhais M, 2009, Toys in physics lectures and demonstrations - a brief review. Physics education, 44(1), 53 - 64.

Hazari, Z., Potvin, G., Lock, R. M., Lung, F., Sonnert, G., \& Sadler, P. M. (2015). Factors that affect the physical science career interest of female students: Testing five 
common hypotheses, 020115, 1-8. http://doi.org/10.1103/PhysRevSTPER.9.020115 acces date: 21.07.2017

Hidayah, A., Yulianto, A., \& Marwoto,P. (2015). Effect of project based learning approach contextual to creativity of student of madrasah, ICMSE, 2015 Retrieved from http://icmseunnes.com/2015/?page_id=563 Access date: 25.07.2017

Husamah (2015). Thinking skills for environmental sustainability perspective of new students of biology education department through blended project based learning model. Jurnal Pendidikan IPA Indonesia Indonesian Journal of Science Education, 4(2), 110119. DOI: 10.15294/jpii.v4i2.3878

Joshi, S.C. (2014). Physics of Gulli-Danda. Physics Education, 30(1), 36-48.

Kara, K. (2008). Ilköğretim 3. Sinif hayat bilgisi dersinde sorgulama merkezli etkinliklerle yapilan proje çalişmalarindaki öğrenci performansinin değerlendirmesi. Çukurova üniversitesi sosyal bilimler enstitüsü eğitim bilimleri anabilim dali, Yükseklisans Tezi.

Karakaş, D., \& Büyükaydın, B. (2016). Physics toys used for efficient learning in physics. International Conference New Perpectives in Science Education.

Karakuş, F. (2006), "Sosyal Bilgiler Öğretiminde Yapıcı Öğrenme ve Otantik Değerlendirme Yaklaşımlarının Öğrencilerin Akademik Başarı, Kalıcılık Ve Sosyal Bilgiler Dersine Yönelik Tutumlarına Etkisi”, Yayınlanmamış Doktora Tezi, Çukurova Üniversitesi Sosyal Bilimler Enstitüsü, Adana.

Ketelhut, D. J., Dede, C., Clarke J., \& Nelson, B. (2006). A multi-user virtual environment for building higher order inquiry skills in science. Paper presented at the 2006 AERA Annual Meeting, San Francisco, CA. Available at http:// muve.gse.harvard.edu/rivercityproject/documents/ rivercitysympinq1.pdf Acces date: 15.07.2017

Kızkapan, O.,\& Bektaş, O. (2017). The Effect of Project Based Learning on Seventh Grade Students' Academic Achievement. International Journal of Instruction, 10(1),3754.

Korhonen. M. (2010). Capstone Project Physics Toys. http://www.fulbright.fi/sites/default/files/Liitetiedostot/Stipendiohjelmat/Suomalaisille/d fat-korhonenmikko-capstone.pdf access date: 13.07.2017

Stege ,L., Lankveld , G.V., \& Spronck, P. (2014). Game Teaching High School Physics with a Serious Game. http://www.spronck.net/pubs/StegeIJCSS2011.pdf Access date: 10.06.2017

Pantiwati, Y., \& Husamah (2017). Self and peer assessments in active learning model to increase metacognitive awareness and cognitive abilities. International Journal of Instruction, 10(4), 185-202. https://doi.org/10.12973/iji.2017.10411 
Şalgam, E. (2009). Fizik Eğitiminde Probleme Dayalı Öğrenme Yönteminin Ögrencilerin Akademik Başarısı ve Tutumlarına Etkisi. Yükseklisans Tezi, Dokuz Eylül Üniversitesi, Eğitim Bilimleri Enstitüsü.

Timurkaan Akçinar, S., Uğraş, S. Timurkaan, H.S. Özen, G.,\& Akçinar, F. (2017). 12. Sınıf Özel Alan Çalışması. Devlet Kitaplari Ikinci Baskı.

Ülküdür M.A., \& Bacanak, A. (2013). Proje tabanli öğrenme etkinlikleri ile oyun tabanli öğrenme etkinliklerinin hazirlik (geliştirilme) boyutunda karşilaştirilmasi. Bayburt Üniversitesi Eğitim Fakültesi, 8(1), 21-43.

Yılmaz, F. N. (2015). Fen Bilimleri Öğretiminde Proje Tabanlı Öğrenme Yaklaşımının 6. Sınıf Öğrenci Başarısı ve Bilimsel Süreç Becerilerine Etkisi. Yükseklisans tezi, Pamukkale Üniversitesi Eğitim Bilimleri Enstitüsü, Fen Bilgisi Eğitimi Anabilim Dalı.

Yurtluk, M. (2003). Proje tabanli öğrenme yaklaşiminin matematik dersi öğrenme süreci ve ögrenci tutumlarina etkisi, Yayımlanmamış Yüksek Lisans Tezi, Ankara: Hacettepe Üniversitesi Sosyal Bilimler Enstitüsü.

(16) Self and Peer Assessments in Active Learning Model to Increase Metacognitive Awareness and Cognitive Abilities. Available from:

https://www.researchgate.net/publication/320014853_Self_and_Peer_Assessments_in_ Active_Learning_Model_to_Increase_Metacognitive_Awareness_and_Cognitive_A ies [accessed Nov 20 2017]. 